\title{
$6060 \mathrm{CECE}$ \\ 最む活性の高いポリオレフィン用触媒
}

Olefin Polymerization Catalyst with Highest Activity

\section{1.はじめに}

重合触媒の活性は，その使用方法や重合条件（温度や 圧力はあちろん溶媒やモノマーの純度に至るまで）によ り, 数倍から数十倍あ変化することが常識である.なお かつ，すべての文献，特許を網羅することむ筆者の手に 余る. そこで本稿では, 日本に出願された特許について, まず主要なむのを選び出し，そこに記載されたデータを 同一単位に換算したのみで, 重合条件その他については 考慮することなく比較検討するという方法を採ることと した. したがって，本稿の議論は実使用時の触媒のラン ク付けには該当しないことをまずお断りしておく.

\section{2. ポリエチレン用触媒}

\section{2-1. チーグラー系触媒}

チーグラー触媒が最初に特許として出願されたのは 1953 年")であり,この時は四塩化チタン $\left(\mathrm{TiCl}_{4}\right)$ とトリ エチルアルミニウムとの組合せであったが，この系の触 媒活性は非常に低く, この後の研究はおもに活性の向上 が目的とされた. その結果, 塩化マグネシウム $\left(\mathrm{MgCl}_{2}\right)$ 担持型触媒が開発され, これは現在でも中心的な触媒と して工業的に使用されている．この触媒の原型はシェル により 1961 年に出願されており ${ }^{2)}, \mathrm{TiCl}_{4}$ を $\mathrm{MgCl}_{2}$ に 担持することにより触媒活性が飛躍的に向上した. この 出願を境に各社でさまざまな担持型触媒が開発された。 特に 1980 年代には高活性を唱った特許が数多く出願さ れており, その触媒活性は $1 \sim 3 \times 10^{4} \mathrm{~kg}-\mathrm{PE} / \mathrm{mol}-\mathrm{Ti}$ ・ $\mathrm{atm} \cdot \mathrm{h}$ と非常に高いものであっだ!. しかしこの後の各 社からの出願は, その多くが生成パウダーの形状やかさ 密度に関するものであり, 触媒活性の向上はそれほど大 きなあのではなかった．その中で, 1988 年にポリアル デン・ペトロ・クイミカから出願された特許では,

$\mathrm{MgCl}_{2}$ と安息香酸エチルとを共粉砕し, さらにアルミナ と共粉砕した担体を使用した触媒がスラリ一重合におい て $2.0 \times 10^{5} \mathrm{~kg}-\mathrm{PE} / \mathrm{mol}-\mathrm{Ti} \cdot \mathrm{atm} \cdot \mathrm{h}$ の活性を示した ${ }^{4)}$. また共重合においては, 触媒活性はコモノマーの種類や 濃度により大きく変化するためよりいっそう比較は困難 となるが，特許における動向は前述した単独重合の場合 と同様であり, 1976 年から 1988 年にかけて $1 \sim 2 \times$ $10^{4} \mathrm{~kg}-\mathrm{PE} / \mathrm{mol}-\mathrm{Ti} \cdot \mathrm{atm} \cdot \mathrm{h}$ 之報告しているあのが数多 く出願されている5!. その後改良が進み, 1993 年に UCC
より出願された特許6)では 1-ヘキセンとの共重合におい て $8.8 \times 10^{4} \mathrm{~kg}-\mathrm{PE} / \mathrm{mol}-\mathrm{Ti} \cdot \mathrm{atm} \cdot \mathrm{h}$ という数值が記載 されている.

\section{2-2. メタロセン系触媒}

1980 年, カミンスキーらはジルコノセンジクロリド とメチルアルミノキサンからなる触媒がエチレンに対し て高い活性を有することを発表した7).この後, この触媒 についてポリマー製造各社がこぞって研究を行った. メ タロセン触媒に関する基本特許は, 1982 年にへキスト が出願したトリメチルアルミニウムから調製したメチル アルミノキサン $(\mathrm{MAO})$ とジシクロペンタジェニルジル コニウムジクロリドとの組合せであり，この触媒系の活 性は $1.6 \times 10^{5} \mathrm{~kg}-\mathrm{PE} / \mathrm{mol}-\mathrm{Ti} \cdot \mathrm{atm} \cdot \mathrm{h}$ であった ${ }^{8)}$. 一方, 1985 年の三井石油化学の特許では, 硫酸アルミニウ ム・14 水和物とトリメチルアルミニウムとから調製し た MAOとジシクロペンタジエニルジルコニウムジク ロリドとの組合せによる触媒系において $9.9 \times 10^{6} \mathrm{~kg}-$ $\mathrm{PE} / \mathrm{mol}-\mathrm{Ti} \cdot \mathrm{atm} \cdot \mathrm{h}$ という活性を示している ${ }^{9)}$. 共重合 に関しても, 三井石油化学から, ベンゼン不溶性 MAO とエチレンビスインデニルジルコニウムジクロリドとの 組合せによりエチレンと 4-メチルー1-ペンテンとを共重 合した場合において $1.3 \times 10^{5} \mathrm{~kg}-\mathrm{PE} / \mathrm{mol}-\mathrm{Ti} \cdot \mathrm{atm} \cdot \mathrm{h}$ という值が示されている10).

\section{3. ポリプロピレン用触媒}

\section{3-1. チーグラー・ナッ夕触媒}

プロピレン重合用触媒として, 工業的に最も重要であ るイソタクチックポリプロピレン $(i-\mathrm{PP})$ 用触媒は, ナッ 夕による初期型三塩化チタン $\left(\mathrm{TiCl}_{3}\right)$ 触媒に始まった が11), 工業的には $\mathrm{TiCl}_{4}$ を金属アルミニウムで還元した $\mathrm{AA}$ 型 $\mathrm{TiCl}_{3}$ を触媒とし, 助触媒にジェチルアルミニウ ムクロリド (DEAC) を用いて, スラリ一重合により生産 が開始された。 AA 型触媒の活性は約 $3 \mathrm{~kg}-\mathrm{PP} / \mathrm{mol}-$ $\mathrm{Ti} \cdot \mathrm{atm} \cdot \mathrm{h}$ 程度であった ${ }^{12)} .1970$ 年代にソルベーは $\mathrm{TiCl}_{4}$ を $\mathrm{DEAC}$ で還元し, ジイソアミルエーテルで処理 した改良型の $\mathrm{TiCl}_{3}$ 触媒を開発したが，この触媒は, 約 $30 \mathrm{~kg}-\mathrm{PP} / \mathrm{mol}-\mathrm{Ti} \cdot \mathrm{atm} \cdot \mathrm{h}$ の活性を示した ${ }^{13)} . i-\mathrm{PP}$ 用 の $\mathrm{MgCl}_{2}$ 担持型 $\mathrm{TiCl}_{4}$ 触媒は三井石油化学により約 $7 \times 10^{2} \mathrm{~kg}-\mathrm{PP} / \mathrm{mol}-\mathrm{Ti} \cdot \mathrm{atm} \cdot \mathrm{h}$ 之飛躍的な改良が行われ た ${ }^{14)}$ ，その後, $\mathrm{MgCl}_{2}$ 担持型でジェステルを含有する触 媒がモンテジソンにより開発された ${ }^{15)}$. 各種マグネシウ 


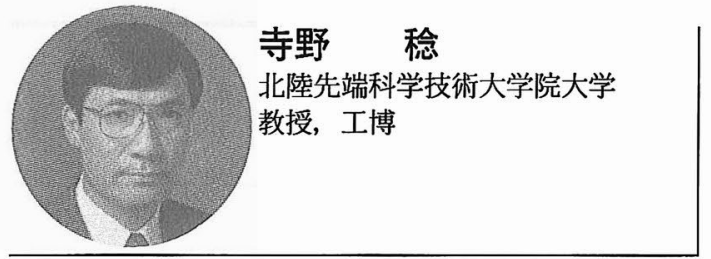

ム化合物を利用するすのを含めて，このタイプが現在の 工業触媒の主流となっており, 活性は $5 \sim 9 \times 10^{3} \mathrm{~kg}$ $\mathrm{PP} / \mathrm{mol}-\mathrm{Ti} \cdot \mathrm{atm} \cdot \mathrm{h}$ にまで達している ${ }^{16) \sim 18)}$.

\section{3-2. メタロセン触媒}

1985 年カミンスキー, ブリンッィンガーらは $\mathrm{C}_{2}$ 対称 性を有するメタロセン化合物であるエチレンビスインデ ニルジルコニウムジクロリドを $\mathrm{MAO}$ と組み合わせる ことで $i-\mathrm{PP}$ の合成に成功したが，その活性は $1.8 \times 10^{3}$ $\mathrm{kg}-\mathrm{PP} / \mathrm{mol}-\mathrm{Zr} \cdot \mathrm{atm} \cdot \mathrm{h}$ であった ${ }^{19)}$. その後, ジメチルシ リレンビス(2,4-ジメチルシクロペンタジェニル)ジルコ ニウムジクロリドがチッソ・理化学研究所において合成 され, この活性は $2.8 \times 10^{3} \mathrm{~kg}-\mathrm{PP} / \mathrm{mol}-\mathrm{Zr} \cdot \mathrm{atm} \cdot \mathrm{h}$ で あった ${ }^{20)}$. へキストでは約 $2.8 \times 10^{4} \mathrm{~kg}-\mathrm{PP} / \mathrm{mol}-\mathrm{Zr}$. $\mathrm{atm} \cdot \mathrm{h}$ という極めて高い活性を示すジメチルシリレン ビス(2-メチル-4-フェニルインデニル)ジルコニウムシ クロリド / MAO 系の触媒が開発された ${ }^{21)}$.メタロセン 触媒としては, この系が最高活性を示すむのと思われ る.一方, MAO 以外の活性化剤としてボレート系カチ オン化剤や変性 MAO などの開発も進められている。ジ メチルシリレンビス(2-メチル-4-フェニルインデニル) ジルコニウムジクロリド/ペンタフルオロフェノールア ルミノキサン系の触媒活性は $1.0 \times 10^{5} \mathrm{~kg}-\mathrm{PP} / \mathrm{mol}-\mathrm{Zr}$. $\mathrm{atm} \cdot \mathrm{h}$ となり ${ }^{22)}$, MAO 使用時の約 40 倍となった.

\section{4.おわりに}

ポリオレフィン用に限らず, 触媒を研究する際には活 性の向上は非常に重要なテーマであるが，チーグラー 系, メタロセン系とあすでに極めて高いレベルに到達し ており, 現在ではむしろ触媒の高機能化に研究の夕一 ゲットが絞られているようである. 今後の研究により, 高活性を維持した上でより優れた機能を併せすった触媒 の出現を期待して本稿を終えることとする.

なお，本稿をまとめるにあたり私の研究室に国内留学 中の川本尚史 (チッソ), 長谷部公一 (旭化成) 両氏に多 大なご協力を頂いた. また, 貞利 甫 (住友化学), 藤田 孝 (三菱化学), 松下文夫 (旭化成), 松川哲也 (チッソ) 各氏から貴重なご意見をいただいた。ここに記して謝意 を表する次第である.

\section{文献}

1) チーグラー：特公昭 32-1545

2）シェル：特公昭 39-12105

3）例えば旭化成：特開昭 61-42510

4) ポリアルデン・ペトロ・クイミカ：特開平 1-113412

5）例えばビーピー・ケミカルズ：特開昭 62-119205

6) UCC：特開平 7-292031

7) H. Sinn, et al.: Angew. Chem., 92, 390 (1980)

8) ヘキスト：特開昭 58-19309

9) 三井石油化学：特開昭 61-211307

10) 三井石油化学: 特開平 2-167309

11) モンテジソン：特公昭 32-10596

12）モンテジソン：特公炤 34-2489

13) ソルベー：特公昭 53-3356

14) 三井石油化学：特公昭 58-5201

15) モンテジソン: 特開昭 57-63310

16) 三菱油化: 特開平 1-266107

17) 東邦チタニウム：特開平 4-8709

18) 住友化学: 特開平 7-216017

19) W. Kaminsky, et al:: Angew. Chem. Int. Ed. Engl., 24, 507 (1985)

20) S. Miya, et al.: Chem. Lett., 1853 (1989)

21) ヘキスト：特開平 6-100579

22) 出光興産: 特開平 6-329714

\section{お知らせ}

昨年（1995 年） 5 月から，「高分子ギネスブック」 の欄を開設し，高分子科学・技術の分野のチャンピ オンデータを紹介しておりますが，このたび，編集 委員会で欄の名称を検討の結果, 11 月号から「高 分子チャンピオンデー夕」と改称することにいたし ました。

掲載のチャンピオンデータは, 執筆者が現時点で知りうる範囲での記述によるあのであり，必ずしあ最高の記録であるとは限り ません，数値についての疑念や，上回る数値の主張，また測定の評価法についての異論や質問を歓迎いたします. 編集委員会 